I. V. Rybitskyi, Cand. Sc. (Tech.), orcid.org/0000-0003-3596-3918, V. I. Trofimchuk, orcid.org/0000-0002-2102-4605, G. M. Kogut, orcid.org/0000-0002-4780-7448
Ivano-Frankivsk National Technical University of Oil and Gas, Ivano-Frankivsk, Ukraine, e-mail: rybitsky@gmail.com

\title{
ENHANCING THE EFFICIENCY OF GAS DISTRIBUTION STATIONS OPERATION BY SELECTING THE OPTIMAL GAS PRESSURE AND TEMPERATURE PARAMETERS AT THE STATION OUTLET
}

Ukraine ranks first in the world in terms of energy intensity per unit of GDP, which means that Ukrainian enterprises spend the most energy in comparison with other countries in the production of the unit of production. The Gas Transportation System (GTS) is no exception. Gas transit is expected to reduce from 2020 due to the construction of gas pipelines bypassing the territory of Ukraine, which will lead to a decrease in the profitability of the GTS and, if not sufficiently loaded, to its loss. That is why ensuring efficient operation of the GTS equipment in terms of energy efficiency is becoming more relevant today than ever.

Purpose. To develop methods for enhancing the energy efficiency of the gas transmission system of Ukraine (based on the analysis of the gas distribution stations (GDS) operation) without significant investment, considering the possible decrease in gas transmission.

Methodology. In the work, the analysis of scientific and technical literature and regulatory documents is performed; mathematical modelling and analysis of operational performance of GDS is performed to determine the economic and environmental effect of the proposed measures.

Findings. It was confirmed that adjusting gas pressure at the outlet to the design pressure is a promising direction for energy efficiency increasing. According to the analysis of scientific and technical literature and regulatory documents, the optimal gas temperature at the outlet of the gas distribution system was determined. It was outlined that the implementation of the developed set of measures will allow obtaining a significant economic and environmental effect.

Originality. The necessity of implementation of a set of cost-free measures was developed and justified, mainly, reduction of the present natural gas indicators of temperature and pressure at the outlet of the gas distribution stations to the optimal ones, which will increase energy efficiency and ecological efficiency of its operation.

Practical value. The results will be used for production activity purposes, during the operation of gas distribution stations

Keywords: energy efficiency, pipeline transportation, gas transmission system, gas distribution station

Introduction. Until recently, one of the main routes for gas transit to Europe ran through the territory of Ukraine. The Ukrainian gas transmission system (GTS) transported about 120 billion cubic meters of gas to Europe (compared to the designed output transit capacity up to 146 billion cubic meters). However, gas infrastructure loading may decrease due to the possible redirection of the entire gas volume to alternative routes. Historically, gas transmission volumes are decreasing, for example, through a partial change of transit routes to alternative (new) ones, bypassing the territory of Ukraine (Yamal, Nord Stream).

Since January 1, 2020, as a result of the unbundling process [1], the natural gas transmission by gas pipelines in Ukraine has been controlled by a new independent operator LLC "GTS of Ukraine Operator" (GTS operator). After the end of the 10-year transmission contract with Gazprom, as a result of tripartite negotiations, a 5-year contract for the transmission of Russian gas was signed. According to the contract, the total transmission volume for 2020-2024 is equal to 225 billion $\mathrm{m}^{3}$, which is approximately $50 \%$ less than the transit for the last 5 years [2].

Above all, since 2005, there has been a decrease in domestic gas consumption, Fig. 1, from 76 billion $\mathrm{m}^{3}$ in 2005 to 30 billion $\mathrm{m}^{3}$ in 2019 [3], which lead to a decrease in the use of GTS for domestic transportation. A clear trend towards a significant reduction in gas consumption in Ukraine is due to both an increase in gas prices and a decrease in gas consumption in the industrial segment.

Taking all abovementioned facts into consideration, the GTS operator should focus its efforts on optimizing the system by reducing the energy intensity of production to optimize energy costs, which in turn will increase the profitability of the company.

(C) Rybitskyi I. V., Trofimchuk V. I., Kogut G. M., 2020
The GTS of Ukraine is a significant consumer of energy resources. According to the Annual Report on Energy resources usage in 2019, the total gas consumption for the needs of the GTS, including all branches and divisions totalled 2321.432 million $\mathrm{m}^{3}$, of which gas consumption for their own engineering and manufacturing demands (EMD) can be roughly divided into three components (Fig. 1): the main component of the costs is fuel gas and electricity for the GCU, the second is the "unbalance" of gas, the third - technical and technological costs, which amounted to 56.7 million $\mathrm{m}^{3}$ or $0.063 \%$ of the volume of gas supplied to the GTS (in 2018, 69.4 million $\mathrm{m}^{3}$, respectively).

The analysis results of annual reports on the use of fuel and energy resources and the transportation operation of the GTS since 2001 are shown on the chart (Fig. 2). The chart shows that the consumption of gas for technical and technological needs, despite the volume of transmission operation, has been steadily declining since 2014 . The reduction of the volume of gas used for technical and technological needs coincides with the period of implementation of the energy management system (EMS) in JSC "UKRTRANSGAZ" in accordance with the requirements of ISO 50001 certificate No. 1234047135 TMS; accredited by DAkkS (Germany) [4]. This suggests that technological costs are mostly subjected to energy management and are not dependent on the amount of gas transported (transmission operation of the GTS). Technological costs consist of the costs for boiler stations' operating in the heating season, the technological costs of verifying the performability of equipment (safety valves, vessels, installations, and others) and fire heaters of natural gas during the operation of gas distribution stations (GDS).

The ways for improving the efficiency of energy resources during the operation of boiler stations for heating the premises were considered in [5], where the specific recommendations 


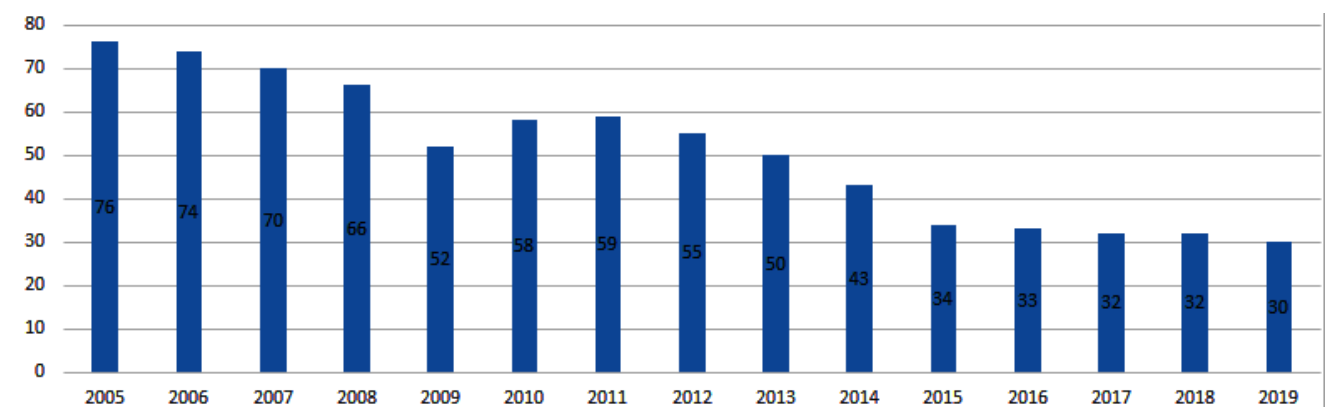

Fig. 1. Consumption of natural gas in Ukraine in 2005-2019, billion $\mathrm{m}^{3}$ [3]

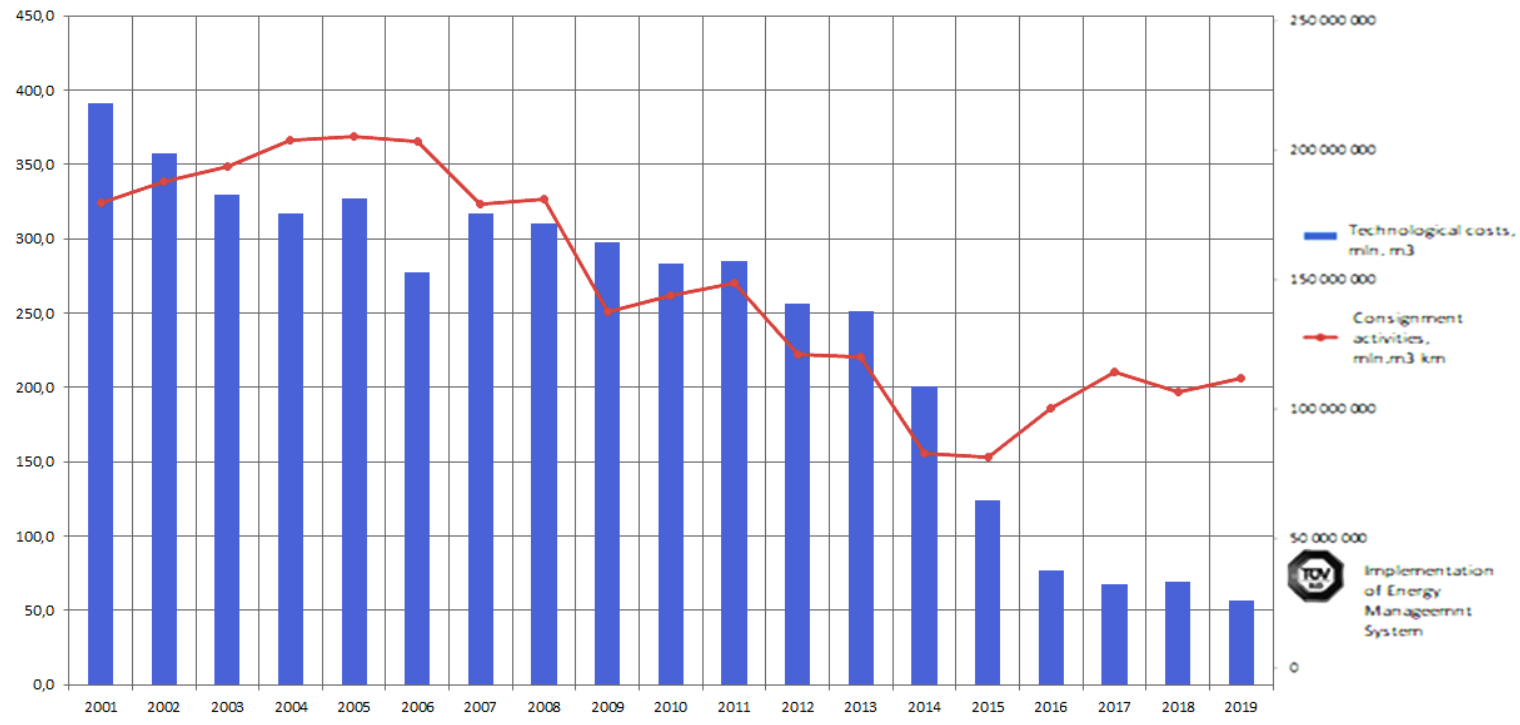

Fig. 2. Technological expenditures and consignment activities of GTS within 2001-2019

for improving energy efficiency and the economic effect of such actions were presented.

The costs of verifying the performability of equipment are carried out with a given frequency and on equipment specified in the technological regulations and equipment passports. This type of technological costs is strictly regulated and is directly related to the safety of gas supply. The areas of energy efficiency will be associated with the rejection of the use of part of the equipment that will not be involved in the operation with a decrease in transmission volumes.

According to the above mentioned information, the authors focused on optimizing the use of energy resources by gas heaters at gas distribution stations.

Gas distribution stations are to reduce the gas pressure from the main gas pipeline to a certain level, which will ensure the safe consumption of natural gas. The following main processes are carried out at the GDS: gas purification from solid and liquid impurities; gas heating; gas pressure decreasing (reduction); gas odorization; gas metering (consumption) before supplying it to the consumers.

Natural gas at a certain temperature and pressure being saturated with water vapours is capable of forming dense formations of gas hydrates on the operating surface of pipelines [6]. To prevent the formation of gas hydrates, the following methods are used: gas heating, heating the pressure regulator body; introduction of methanol into the gas pipeline.

The method of general or partial gas heating has found the widest application. The cost of heaters is high and depends on thermal power, capacity and equipment. This method is financially costly, but it allows maintaining constantly the required gas temperature regardless of the electricity supply and is safe for personnel ensuring the autonomy of the GDS and the safety of gas supply to the population.
Unsolved aspects of the problem. When the gas pressure at the GDS decreases, its temperature drops sharply and gas hydrates can form on the surface of the valves and pressure regulators' seats, which will lead to their failure and cause a complete stop of the GDS. To prevent the formation of gas hydrates, natural gas is heated to the appropriate temperature.

The normative documents regulating the operation of the GTS of Ukraine do not regulate the gas temperature at the outlet of the GDS. This situation dates back to Soviet times, when the focus was on the reliability of the system, and no one paid attention to the cost of energy resources, due to their low cost. It is clear that today the reliability of gas supply is and should remain a priority of the GTS operation, but a significant increase in the cost of energy resources forces to look for energy-efficient approaches to such systems' operation.

Purpose. According to the given purpose, the following goals are formulated:

- to analyse the value of the gas dew point temperature in the main transmission gas pipelines and the requirements of regulatory documents governing the operation of gas distribution stations to determine the optimal gas temperature;

- to analyse the average temperature, pressure and gas flow rate at the selected gas distribution stations to determine its savings at the optimal outlet gas temperature;

- to determine the economic and environmental effect of increasing the gas pressure at the outlet of the gas distribution system to the designed one.

Literature review. The problem of optimizing the operation of gas heaters is studied quite deeply by many scientists; in particular, in [7] it was proposed to use turbo-expanders on gas distribution stations to reduce pressure, to compensate the part of the energy consumed at compressor stations. In [8], the processes of heat transfer and pressure drop on a GDS heater 
with a heating element in the form of a conductor on a tube insert and the effect of changes in the geometric parameters of the tube were studied. Based on the studies, it is proved that the placement of the corresponding pipe inserts in heat exchangers leads to an increase in their heat coefficient

The above mentioned methods for increasing the energy efficiency of the gas heating process at gas distribution stations require investments from 50 to 500 thousand dollars USA and have a payback period of 2 to 15 years. In this article it is proposed to apply measures that do not require significant investments, and their implementation requires only the implementation of certain managerial decisions in the operation of the gas distribution system.

Results. As described above, when the gas pressure on the GDS regulators decreases, its temperature decreases as well, and its value after the regulating unit can be described by the following dependence [9]

$$
T_{2}=T_{1}-D_{i} \cdot\left(P_{1}-P_{2}\right),
$$

where

$$
D_{i}=\frac{T_{1}-T_{2}}{P_{1}-P_{2}},
$$

where $T_{1}, T_{2}$ are temperatures of natural gas before and after the regulating unit respectively, $\mathrm{K} ; P_{1}, P_{2}$ are pressure of natural gas before and after the regulating unit respectively, $\mathrm{MPa}$; $D_{i}$ is the Joule-Thomson coefficient, K/MPa.

The overconsumption of natural gas at GDS per day is obtained by the formula

$$
Q_{o c}=\frac{Q_{\text {het }}}{T_{2 \text { calc }}-T_{2 r}}\left(T_{2 r}-T_{2 g}\right),
$$

where $Q_{\text {het }}$ is gas quantity used for natural gas heating per day, $\mathrm{m}^{3} ; T_{2 \text { calc }}$ is gas temperature at the outlet of GDS according to the formula (1), $0 \mathrm{~K} ; T_{2 e}$ is the actual temperature of heated gas at the outlet of GDS, ${ }^{\circ} \mathrm{C} ; T_{2 g}$ is the minimum permissible temperature at the outlet of the GDS, K.

The authors analysed the operation of all GDSs (Table 1), which are part of the Gas Main Pipeline Division "Cherkasytransgaz" (GMPD "CTG") and found that out of 199 GDSs, gas heaters are only operated 161 GDSs.

According to the data from Table 1, the design output pressure is set at only 11GDS. By agreement with gas supply organizations, the outlet pressure was reduced by 150 GDS to optimize the pressure drop zone at the measuring units. The pressure was decreased from 0.01 to $0.09 \mathrm{MPa}$. The average pressure drop was $0.43 \mathrm{MPa}$.

After calculating (1) for each GDS, it is established that the average Joule-Thomson coefficient is $5.42 \mathrm{~K} / \mathrm{MPa}$.

To verify the calculation, the Joule-Thomson coefficient was applied to GDSs without gas heaters and compared to the actual gas temperature at the outlet of GDSs. The average temperature difference was less than $0.5^{\circ} \mathrm{C}$, which confirms the correctness of the calculations. Summary of the actual performance of one of the selected for comparing GDS and the results of comparative calculations on it are given in Table 2 .

To determine the economic effect of bringing the pressure at the outlet of the GDS to the designed pressure, it is necessary to determine the increase in temperature at the outlet of the GDS in the case of increasing the pressure by $4.3 \mathrm{~atm} .=$ $=0.43 \mathrm{MPa}$.

According to the formula (2) it is determined

$$
\begin{aligned}
& \left(T_{2 r}-T_{2 g}\right)=D_{i} \times P_{\text {incr }} ; \\
& T_{\text {incr }}=0.43 \cdot 5.42=2.3,
\end{aligned}
$$

where $P_{\text {incr }}$ is pressure increasing at the outlet of GDS, MPa; $T_{\text {incr }}$ is temperature increasing at the outlet of GDS, K.
Table 1

Analysis of GDS operation at GMPD "CTG" according to the pressure data at the outlet of GDS using the ASK software

\begin{tabular}{|l|c|}
\hline \multicolumn{1}{|c|}{ Parameters } & GDS, number \\
\hline Designed pressure & 11 \\
\hline $\begin{array}{l}\text { Decreasing of the designed pressure out of all } \\
\text { at(MPa): }\end{array}$ & 150 \\
\hline 0.01 & 13 \\
\hline 0.02 & 8 \\
\hline 0.03 & 51 \\
\hline 0.04 & 32 \\
\hline 0.05 & 2 \\
\hline 0.06 & 4 \\
\hline 0.07 & 3 \\
\hline 0.08 & 9 \\
\hline 0.09 & 28 \\
\hline
\end{tabular}

${ }^{*}$ ASK - software, which in real time shows the parameters of the equipment and the characteristics of natural gas during the operation of the GDS

The obtained data are put into the formula (3) and the result is the amount of gas, which is additionally consumed by the heater to heat the gas to a temperature $T_{\text {incr }}$ per day.

$$
Q_{o c}=\frac{Q_{h e t}}{T_{2 \text { calc }}-T_{2 r}} T_{\text {incr }} .
$$

Using the ASK software, the average gas temperature at the outlet and the average gas consumption of each of the 150 GDS, belonging to GMPD "Cherkasytransgaz". The given GDS are equipped with gas heaters and perform the entire array of data, which is about 70000 calculations, was calculated using Mathcad. Qos is $170423 \mathrm{~m}^{3}$.

The cost of gas consumed is calculated by the formula, thousand UAH

$$
C=Q_{o s} \cdot P=1891,
$$

where $P$ is gas average price for industry in 2018 according to [10].

The obtained cost value of the gas is estimated, but its value confirms the prospects of this area of GDS management, in order to improve its energy efficiency. To obtain the accurate values of the costs of gas overconsumption for all GDSs, it is necessary to perform calculations for each of them individually, taking into account the actual values of pressure and temperature of the gas.

After analysis of the requirements of the current normative documents governing the activity of the GDS, the authors found that, the state building codes of Ukraine in force up to 2018 set the temperature of gas at the outlet of GDS of the main gas pipelines, when fed into underground gas pipelines, not being less than minus $10{ }^{\circ} \mathrm{C}$ [11]. This norm was determined in order to prevent the formation of icing of underground gas pipelines and, as a consequence, the occurrence of emergencies. In the current building codes of Ukraine from 2018 [12] this rule is absent, but all studied GDS were constructed before 2018 and underground gas pipelines are designed for gas temperatures up to minus $10{ }^{\circ} \mathrm{C}$.

To prevent the formation of hydrates in the pipeline, the gas temperature should be higher than the dew point [13]. The dew point of the gas in the GTS pipelines is minus $8^{\circ} \mathrm{C}$ at an absolute gas pressure of 3.92 MPa [14].

The authors also analysed the dew point temperature in the main transmission gas pipelines of the GMPD "Cherkasytrans- 
Actual indicators of GDS operation

\begin{tabular}{|c|c|c|c|c|c|c|c|}
\hline \multirow{2}{*}{ Data } & \multirow{2}{*}{$\begin{array}{c}\text { Gas volume, } \\
\text { transported to the } \\
\text { customer }\end{array}$} & \multicolumn{2}{|c|}{$\begin{array}{l}\text { Gas pressure } \\
\left(\mathrm{kg} / \mathrm{cm}^{2}\right)\end{array}$} & \multicolumn{2}{|c|}{$\begin{array}{l}\text { Gas temperature; } \\
\text { actual }\left({ }^{\circ} \mathrm{C}\right)\end{array}$} & \multirow{2}{*}{$\begin{array}{c}\text { Gas temperature } \\
\text { at the GDS outlet, } \\
\text { formula }(3) \\
\left({ }^{\circ} \mathrm{C}\right)\end{array}$} & \multirow{2}{*}{$\begin{array}{c}\begin{array}{c}\text { Difference between } \\
\text { actual and calculated } \\
\text { temperature }\end{array} \\
\left({ }^{\circ} \mathrm{C}\right)\end{array}$} \\
\hline & & inlet & outlet & inlet & outlet & & \\
\hline 01.01 .2018 & 439348 & 27.1 & 2.5 & 9 & -4.5 & -4.28 & 0.22 \\
\hline 03.01 .2018 & 488220 & 27 & 2.5 & 9.1 & -4.05 & -4.38 & 0.33 \\
\hline 05.01 .2018 & 536523 & 27 & 2.5 & 9.2 & -4.11 & -4.28 & 0.17 \\
\hline 07.01.2018 & 469539 & 27.5 & 2.5 & 9.4 & -3.8 & -4.35 & 0.55 \\
\hline 09.01 .2018 & 645190 & 26.1 & 2.5 & 8 & -4.46 & -4.98 & 0.52 \\
\hline 11.01.2018 & 677904 & 26.5 & 2.5 & 9 & -3.78 & -4.2 & 0.42 \\
\hline 13.01 .2018 & 756138 & 26 & 2.5 & 9 & -4.05 & -3.93 & 0.12 \\
\hline 15.01 .2018 & 861825 & 27.3 & 2.5 & 9.2 & -3.95 & -4.44 & 0.49 \\
\hline 17.01 .2018 & 625184 & 28.4 & 2.5 & 9.2 & -4.54 & -5.05 & 0.51 \\
\hline 19.01.2018 & 522778 & 28 & 2.5 & 8.2 & -5.78 & -5.83 & 0.05 \\
\hline 21.01 .2018 & 500650 & 27.5 & 2.5 & 8 & -6.08 & -5.75 & 0.33 \\
\hline 23.01.2018 & 645110 & 27.7 & 2.5 & 8.1 & -6.66 & -5.76 & 0.9 \\
\hline 25.01 .2018 & 676110 & 27.1 & 2.5 & 8 & -5.91 & -5.53 & 0.38 \\
\hline 27.01.2018 & 638018 & 26.6 & 2.7 & 8 & -4.98 & -5.15 & 0.17 \\
\hline 29.01 .2018 & 423737 & 26 & 2.7 & 8 & -4.55 & -4.82 & 0.27 \\
\hline 31.01 .2018 & 519599 & 26 & 2.7 & 8 & -4.99 & -4.82 & 0.17 \\
\hline Average & 589117 & 26.7 & 2.5 & 8.6 & -4.76 & -4.84 & 0.35 \\
\hline
\end{tabular}

gaz": "Soyuz", "Urengoy-Pomary-Uzhhorod", "Progress" and "Kremenchuk-Ananiev-Bohorodchany" for 2017-2018 and determined that the highest dew point for the studied period was minus $10.3{ }^{\circ} \mathrm{C}$ [4]. As the average pressure at the outlet of the GDS is $0.3 \mathrm{MPa}$, according to [15] the hydrate deposition in the pipeline at such pressure will occur at a gas temperature of minus $33.4^{\circ} \mathrm{C}$. To ensure safe transportation and due to the inertness of maintaining the temperature, the gas temperature should be kept at $5 \mathrm{~K}$ higher than the minimum [16].

From the above given it can be concluded that the gas temperature at the outlet of the GDS can be maintained in the range from -5 to $-10^{\circ} \mathrm{C}$.

Using the ASK software complex, the average gas temperature at the outlet and the average gas consumption of each of the 161 GDSs at GMPD "Cherkasytransgaz" that have gas heaters for 2018 were analysed.

As mentioned above, the optimum gas temperature at the GDS outlet should be at minus $5{ }^{\circ} \mathrm{C}$. To determine the economic effect of bringing the gas temperature at the GDS outlet to the minimum allowable requirements in formula (3) instead of the value of $T_{2 g i v}$ the value of minus $5^{\circ} \mathrm{C}$ is set. The entire data set, which is more than 73 thousand calculations, were grouped by reporting periods (months) and posted in Table 3 .

The volume of gas consumed by the GDS fire heaters at $-5^{\circ} \mathrm{C}$ gas temperature is calculated by the formula

$$
Q_{\text {opt. }}=Q_{\text {cons. }}-Q_{O C},
$$

where $Q_{\text {cons }}$ is the volume of gas consumed by the GDS heaters.

According to the calculations provided the following charts of the actual consumption of natural gas for fire heaters to the simulated consumption with the temperature minus $5{ }^{\circ} \mathrm{C}$ at the outlet of the GDS (Fig. 3).

The area of the blue shape is for the gas saving at a given gas outlet temperature of $5^{\circ} \mathrm{C}$ compared to the actual.

As can be seen from Table $3 Q_{o c}$ for 2018 is $274717 \mathrm{~m}^{3}$. According to [12], the average gas price for industry for 2018 amounted to $11096 \mathrm{UAH}$
Table 3

Calculated data of GDS operation according to the reported period

\begin{tabular}{|c|c|c|c|}
\hline Period & $\begin{array}{c}\text { Volume of gas } \\
\text { consumed by } \\
\text { GDS fire } \\
\text { heaters }\left(\mathrm{m}^{3}\right)\end{array}$ & $\begin{array}{c}\text { Qoc } \\
\text { according to } \\
\text { formulae }(3) \\
\left(\mathrm{m}^{3}\right)\end{array}$ & $\begin{array}{c}\text { Volume of gas } \\
\text { consumed by the GDS } \\
\text { heaters at the gas outlet } \\
\text { temperature }-5{ }^{\circ} \mathrm{C}\left(\mathrm{m}^{3}\right)\end{array}$ \\
\hline 01.2018 & 323128 & 52192 & 270936 \\
\hline 02.2018 & 307665 & 39761 & 267904 \\
\hline 03.2018 & 321661 & 62520 & 259141 \\
\hline 04.2018 & 51059 & 9167 & 41892 \\
\hline 05.2018 & 3127 & 1120 & 2007 \\
\hline 06.2018 & 1801 & 1008 & 793 \\
\hline 07.2018 & 1935 & 232 & 1703 \\
\hline 08.2018 & 1563 & 446 & 1117 \\
\hline 09.2018 & 7647 & 2471 & 5176 \\
\hline 10.2018 & 44422 & 8807 & 35615 \\
\hline 11.2018 & 183840 & 35546 & 148294 \\
\hline 12.2018 & 292687 & 61448 & 231239 \\
\hline Total & $\mathbf{1 5 4 0 5 3 5}$ & $\mathbf{2 7 4 7 1 7}$ & $\mathbf{1 2 6 5 8 1 8}$ \\
\hline
\end{tabular}

Thus, according to (6) the cost of gas overconsumption is equal to 3048.07 thousand UAH in 2018.

Therefore, the total savings from the proposed measures, in particular bringing the pressure on the GDS to the designed one and setting the gas temperature minus $5^{\circ} \mathrm{C}$ at the outlet of the GDS could be

$$
Q_{s}=Q_{s(1)}+Q_{s(2)}=445140,
$$




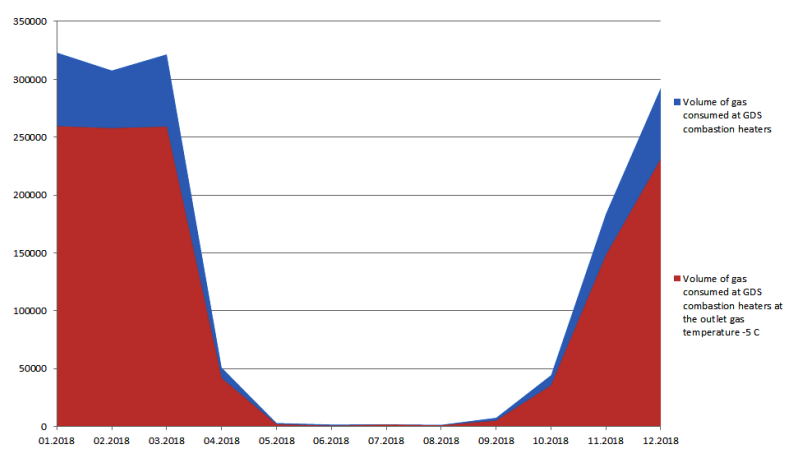

Fig. 3. Comparison of the amount of actual gas consumption at fire heaters with simulated costs with the gas temperature minus $5{ }^{\circ} \mathrm{C}$ at the outlet of the gas distribution station

where $Q_{s(1)}$ is savings of natural gas on gas heaters from bringing the gas pressure at the GDS outlet to the designed one, $\mathrm{m}^{3}$; $Q_{s(2)}$ is savings of natural gas on gas heaters from setting the gas temperature minus $5{ }^{\circ} \mathrm{C}$ at the outlet of the GDS.

Along with the economic effect of implementing these measures, it is also to take into account environmental effect. Natural gas combustion produces compounds such as carbon monoxide, nitric oxide, and other lightweight non-methane compounds, which are some of the most common greenhouse gases in nature [17]. Mass consumption of natural gas per year is calculated by the formula

$$
C=Q_{s} \cdot \rho=309.8,
$$

where $C$ is mass consumption of natural gas per year, t; $Q_{s}$ is the total volume of saved gas $\left(\mathrm{m}^{3}\right)$; $\rho$ is natural gas density under normal conditions, $\mathrm{kg} / \mathrm{m}^{3} ; \rho=0.696 \mathrm{~kg} / \mathrm{m}^{3}$ [4].

According to [18], emissions of pollutants Ei(t) entering the atmosphere with flue gases for the reporting period are found by the formula

$$
E=10^{-6} \cdot R \cdot B \cdot Q_{\text {comb }},
$$

where $E$ is gross emission of pollutants during natural gas combustion for the reporting year, tonnes; $R$ is the emission index of the $i^{\text {th }}$ pollutant for natural gas, $\mathrm{g} / \mathrm{GJ} ; B$ is consumption of natural gas for the reported year, tonnes; $Q_{\text {comb }}$ is lower operating calorific value of natural gas, $\mathrm{MJ} / \mathrm{kg}$.

Calculation results are given in Table 4.

Conclusions. The proposed energy-efficient measures to manage the operation of the GDS at the Gas Main Pipeline Division "Cherkasytransgaz", in particular bringing the pressure and temperature of natural gas to the designed and regulatory requirements, will allow getting the savings of about 6 million UAH per year, as well as obtaining the environmental effect of reducing emissions of pollutants, namely $\mathrm{CO}_{2}$ by

Table 4

Calculation of pollutant emissions from natural gas

\begin{tabular}{|c|c|c|c|c|}
\hline 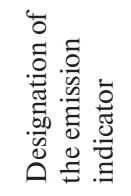 & 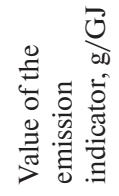 & 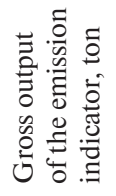 & 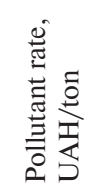 & 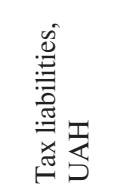 \\
\hline $\mathrm{NO}_{x}$ & 64.3111 & 0.977 & 2454.81 & 2399.10 \\
\hline $\mathrm{CO}$ & 248.75 & 3.780 & 92.37 & 349.17 \\
\hline $\mathrm{CO}_{2}$ & 58748.13 & 892.769 & 10 & 8927.69 \\
\hline \multirow[t]{2}{*}{$\mathrm{CH}_{4}$} & 1 & 0.015 & 138.57 & 2.11 \\
\hline & Total: & 897.541 & & 11678.06 \\
\hline
\end{tabular}
combustion
892.7 tons, $\mathrm{CO}$ by 3.8 tons, $\mathrm{NO}_{x}$ by 0.977 tons, $\mathrm{CH}_{4}$ by 0.015 tons, when considering the given calculation of gas consumption volumes.

Possibility, safety, necessity and energy efficiency of gas transmission to consumers with temperatures below zero and normative value of pressure were proved.

\section{References.}

1. Legislation of Ukraine (n.d.). Resolution of the Cabinet of Ministers of Ukraine No. 840 "On the separation of natural gas transportation activities and ensuring the activities of the gas transmission system operator" of 18.09.2019. Retrieved from https://zakon.rada.gov.ua/laws/show/840-2019-\%D0\%BF. 2. Ukrinform (2020). Gas start 2020: a new contract, European rules and ... higher prices. Retrieved from https://www.ukrinform.ua/rubric-economy/2849463-gazovij-start2020-novijkontrakt-evropejski-pravila-i-visi-cini.html.

3. Naftogaz group (n.d.). Volumes of gas use in 2019. Retrieved from http:/www.naftogaz.com/www/3/nakweb.nsf/0/8B3289 E9F4B2CF50C2257F7F0054EA23?OpenDocument\&Expa nd $=7 \&$.

4. Naftogaz. Ukrtransgaz (2019). The quality of gas. Retrieved from http://utg.ua/utg/business-info/yakst-gazu.html.

5. Trofimchuk, V.I. (2018). Experience of the system of targeted energy monitoring and internal benchmarking at the branch of UMG "Cherkasytransgaz". Naftohazova haluz Ukrainy, (51), 3-8.

6. Rybitskyi, I.V., Oliynyk, A.P., Yavorskyi, A.V., Karpash, O. M., Karpash, M. O., Tsykh, V.S., \& Slobodyan, M. B. (2019). Impact Assess-ment of Non-Technological Fluid Accumulations in the Cavity of an Existing Gas Pipeline on the Energy Efficiency of Its Operation. Physics and chemistry of solid state, 20(4), 457-466. https://doi.org/10.15330/pcss.20.4.457466.

7. Krushnevych, S. P., Piatnychko, A. Y., Zhuk, H. V., \& Soltanybereshne, M.A. (2016). The use of differential pressure at gas distribution stations to produce electrical energy during periods of peak loads. Energotekhnologii i resursozberezhenye, (4), 14-17.

8. Saham Salari, \& Koorosh Goudarzi (2017). Heat transfer enhancement and fuel consumption reduction in heaters of CGS gas stations. Case Studies in Thermal Engineering, 10, 641-649. https://doi.org/10.1016/i.csite.2017.11.007.

9. Redko, A., \& Babenko, E. (2014). Hydrate formation in a gas ejector. Commission of motorization and energetics in agriculture, 16(6), 19-26.

10. Naftogaz group (n.d.). The price of gas for industry. Retrieved from http://www.naftogaz.com/www/3/nakweb.nsf/0/ 486E117B34CF13EEC2257BCE0041B995?OpenDocument.

11. Derzhbud Ukrainy (2001). DBN V.2.5-20-2001. Gas supply. State construction standards. Engineering equipment of buildings and structures. Art.1.6 Retrieved from http://www. rasko.ua/assets/files/B.2.5-20-2001gaz.pdf.

12. DBN V.2.5-20:2018. Gas supply. Engineering equipment of buildings and structures. State construction standards. Art. 4.14.8. Retrieved from https://dbn.co.ua/load/normativy/ $\mathrm{dbn} / 1-1-0-360$.

13. Consortium Kodeks (n.d.). GOST 5542-87 “Combustible natural gases for industrial and municipal purposes. Technical conditions" Art. 1.2. Retrieved from http://docs.cntd.ru/document/gost-5542-87.

14. Code of the gas transportation system of Ukraine. Approved by the Resolution of the NCRECP of 30.09.2015 No.2493, III.1.p.13.

15. DSTU ISO 6327:2004. Gas analysis. Determination of the dew point of water of natural gas. Hygrometers with a cooled surface (ISO 6327:1981, IDT), p. 6.

16. Rozghoniuk, V. V., Rudnik, A. A., Kolomeiev, V. M., Hryhil, M.A., Bolokan, O. O., Khachikian, L.A., \& Herasymenko, Yu. M. (2001). Handbook of the employee of the gas transportation enterprise. Kyiv: Rostok. 
17. Levytskyi, M.A., Miedviedieva, N.A., Sukhenko, V.Yu., \& Demydenko, O.O. (2018). Reporting and verification of greenhouse gas emissions. Standartyzatsiia. Sertyfikatsiia. Yakist, (4), 69-78. Retrieved from http://nbuv.gov.ua/UJRN/ ssia_2018_4_9.

18. Determination of emissions from stationary sources (2016). Visnyk pro podatky, 32(889). Retrieved from http:// www.visnuk.com.ua/ua/news/id/3138.

\section{Підвищення ефективності роботи газорозподільчих станцій шляхом вибору оптимального тиску та температури газу на виході}

\section{I. В. Рибіцький, В. І. Трофімчук, Г. М. Когут}

Івано-Франківський національний технічний університет нафти і газу, м. Івано-Франківськ, Україна, е-таil: rybitsky@gmail.com

Україна займає перше місце у світі за інтенсивністю використання енергії на одиницю ВВП. Це означає, що підприємствами України на виготовлення одиниці продукції витрачається найбільше енергоносіїв у порівнянні з іншими країнами світу. Не є виключенням і Газотранспортна система України (ГТС). Із 2020 року очікується зменшення транзиту газу у зв'язку з будівництвом газопроводів в обхід території України, що приведе до зменшення рентабельності ГТС, а при недостатньому завантажені - до ії збитковості. Тому сьогодні завдання раціональної експлуатації обладнання ГТС із точки зору енергоефективності набуває все більшої актуальності.

Мета. Розроблення комплексу заходів підвищення енергоефективності роботи газотранспортної системи України на основі аналізування роботи газорозподільчих станцій (ГРС) без залучення суттєвих капіталовкладень 3 урахуванням умов можливого зменшення транспортування газу.

Методика. У роботі проведено аналіз науково-технічної літератури, нормативних документів, виконане математичне моделювання та аналіз експлуатаційних показників роботи ГРС для визначення економічного та екологічного ефекту запропонованих заходів.

Результати. Підтверджено, що доведення тиску газу на виході до проектного $є$ перспективним напрямом підвищення енергоефективності. На основі аналізу науково-технічної літератури та нормативних документів визначена оптимальна температура газу на виході із ГРС. Показано, що впровадження запропонованого комплексу заходів дозволить отримати значний економічний та екологічний ефект.

Наукова новизна. Розроблена та обгрунтована необхідність упровадження комплексу безвитратних заходів, зокрема приведення фактичних показників температури та тиску природного газу на виході з ГРС до оптимальних, що підвищить енергоефективність та екологічність іiі експлуатації.

Практична значимість. Отримані результати будуть використані у виробничій діяльності для підвищення енергоефективності експлуатації ГРС.
Ключові слова: енергоефективність, трубопровідний транспорт, газотранспортна система, газорозподільна станція

\section{Повышение эффективности работы газораспределительных станций путем выбора оптимального давления и температуры газа на выходе}

\author{
И. В. Рыбицкий, В. И. Трофимчук, Г. М. Когут
}

Ивано-Франковский национальный технический университет нефти и газа, г. Ивано-Франковск, Украина, e-mail: rybitsky@gmail.com

Украина занимает первое место в мире по интенсивности использования энергии на единицу ВВП. Это означает, что предприятиями Украины на изготовление единицы продукции тратится больше энергоносителей по сравнению с другими странами мира. Не является исключением и Газотранспортная система Украины (ГТС). С 2020 года ожидается уменьшение транзита газа в связи со строительством газопроводов в обход территории Украины, что приведет к уменьшению рентабельности ГТС, а при недостаточной загруженности - до ее убыточности. Поэтому сегодня задача рациональной эксплуатации оборудования ГТС с точки зрения энергоэффективности приобретает все большую актуальность.

Цель. Разработка комплекса мероприятий по повышению энергоэффективности работы газотранспортной системы Украины на основе анализа работы газораспределительных станций (ГРС) без привлечения существенных капиталовложений с учетом условий возможного уменьшения транспортировки газа.

Методы. В работе проведен анализ научно-технической литературы, нормативных документов, выполнено математическое моделирование и анализ эксплуатационных показателей работы ГРС для определения экономического и экологического эффекта предложенных мероприятий.

Результаты. Подтверждено, что доведение давления газа на выходе до проектного является перспективным направлением повышения энергоэффективности. На основе анализа научно-технической литературы и нормативных документов определена оптимальная температура газа на выходе из ГРС. Показано, что внедрение разработанного комплекса мероприятий позволит получить значительный экономический и экологический эффект.

Научная новизна. Разработана и обоснована необходимость внедрения комплекса беззатратных мероприятий, в частности приведения фактических показателей температуры и давления природного газа на выходе из ГРС к оптимальным, что повысит энергоэффективность и экологичность ее эксплуатации.

Практическая значимость. Полученные результаты будут использованы в производственной деятельности для повышения энергоэффективности эксплуатации ГРС.

Ключевые слова: энергоэффективность, трубопроводный транспорт, газотранспортная система, газораспределительная станция

Recommended for publication by P.M. Raiter, Doctor of Technical Sciences. The manuscript was submitted 24.10.19. 